\title{
The creation of conditions for schoolchildren's harmonious development: myth or modern realities
}

\author{
T.M. Trifonova*, and D. A. Malyavin \\ Pacific National University, Tikhookeanskaya st., 136, 680035 Khabarovsk, Russia
}

\begin{abstract}
The article deals with the problem of the harmonious development of schoolchildren in the city of Khabarovsk. The key components for the harmonious development of the personality of a modern student are shown theoretically. The survey data of schoolchildren of grades 6-11 on the subject of their satisfaction with the organization of the educational process have been presented. The analysis of the respondents' answers revealed a complete discrepancy between the real conditions of teaching modern schoolchildren to those components that are necessary for the harmonious development of the child's personality in the system of lifelong education. In the studied educational institutions of Khabarovsk priority is given mainly to the learning process. The educational process is often implemented in only one direction to the detriment of other areas of education. The results obtained define the problem of determining the causes of such stagnation, as well as the conditions conducive to the development of active, harmoniously developed people.
\end{abstract}

\section{Introduction}

One of the crucial tasks of modern Russian education is to prepare a harmoniously developed personality ready for life in a constantly changing world [1]. Besides, a dynamically developing society itself will always need socially active, harmoniously developed people who will be able to independently take all decisions in a dynamically developing society [2]. That is why, according to I.A. Cherkashin, the future of society will be related to solving the problems of educating the younger generation from the standpoint of the new foundations of modern education [3]. They proceed from the self-worth and uniqueness, as well as the person's integrity, from the active tendency of self-development and the development of their capabilities. In accordance with this, the task of the modern school is not the formation of any positive personality traits, but the creation of conditions for its holistic deployment, the formation of adequate life values in young people on the basis of the harmonious development of their internal capabilities [4]. An analysis of the publications of different authors shows that "innovations" are actively introduced in the modern educational environment, which are usually aimed at one-sided personal

\footnotetext{
${ }^{*}$ Corresponding author: zam-obcsh@mail.ru
} 
development [3]. In world practice research into the problem of personal harmony has a long history, which has roots stretching back into antiquity. This can be explained by the fact that the very idea of harmony corresponds to people's primordial need in a prosperous coexistence with nature. The ancient Greek philosopher Aristotle understood harmony as the completeness of a single whole, as unity in diversity and applied this concept to all areas of reality. In the works of G.V. Hegel there is an idea that social harmony is "the unity and struggle of opposites". I. G. Pestalozzi claimed that the balance of social abilities and individual hobbies is understood as the foundation for the education of a harmonious personality, a condition for happiness and life in harmony. According to E. Shaftesbury, mental and physical health is based solely on a uniform ratio of elementary functions [1]. According to L.S. Vygotsky, harmony is a kind of commensurability of parts and the whole, the combination of different components of an object into a single organic whole [5]. In the article by N.N. Lyubimova and O.F. Neskrybina "Harmony" aims to combine the idea of a rationally arranged world with the highest human ability - the ability of aesthetic experience [6]. There is no doubt that the transformation of all spheres of human life required a review and rethinking of the system of upbringing and education of the younger generations that has already existed for a long time. Therefore, the full development of the individual accompanied by the maximum realization of the abilities of each child has become one of the main goals of lifelong education in our country. The realization of this purpose is assumed in general educational institutions as the initial stage of personality formation. Education is a global world value; culture is the environment of education; people are the guardians and carriers of values and education. In today's world, the appreciation of the value of education is considered at the international, state, and personal levels of its prestige [7]. This means that modern educational institutions must create all the necessary conditions for the harmonious development of the child's personality. However, Russian scientists have identified the fact that the system of school education in recent decades has undergone significant changes, not for the better. These days, the primary direction in the education system is the process of learning but not education [8]. If there is educational work in some institutions of the educational system, then often priority is given to one type of educational work while all others are significantly reduced. Therefore, the purpose of the work is to identify the compliance of the conditions for organizing the educational process with the requirements of the harmonious development of the individual in the educational institutions in Khabarovsk.

\section{Materials and Methods}

Our survey was conducted using the Google Forms platform. Google Forms is an online tool that allows creating forms for data collection, online testing and voting. Most frequently, Google forms are used to survey the urban population or customers of various companies or to conduct testing among students and schoolchildren. Secondary schoolchildren from Khabarovsk took part in our survey. The total number of respondents is 178 people. The survey was conducted in absentia. The anonymity of this questionnaire allowed us to obtain the most accurate results of the study. The survey participants, who were schoolchildren of grades 6-11, were asked to answer 22 questions. The questionnaire was sent to the students via WhatsApp. 


\section{Analysis of the main ERS data sources for the DEM development}

The following was revealed during the analysis of the survey of students of general education institutions of Khabarovsk Territory. Among the respondents, the number of those satisfied with the level of teaching in a general education institution was only $37.6 \%$ of the total number of participants in the study. Unsatisfied - 36\% and those who found it difficult to give an answer $-26.4 \%$. At the same time, $44.4 \%$ of students are fully satisfied with the level of their knowledge in the principal subjects.

The positive moral education of a child requires the establishment and preservation of favourable relationships with peers as well as people of different generations. In our study $61.2 \%$ of respondents expressed satisfaction with their relationships with teachers, and $60.9 \%$ - with their peers. The answers of the rest were divided approximately equally, some of the children were not satisfied, the rest found it difficult to give an answer. Perhaps among these children there are those who have not developed the ability to establish contact with peers and older people. Probably these are those schoolchildren who for certain reasons do not know how to quickly adapt to a changing environment. And in this case, the task of educational institutions should be to help such children build communication skills with their peers through various activities. But there is also a gap here.

The child's intellectual education is one of the directions of the pedagogical process of the harmonious development of the child's personality since the foundations of material and spiritual wealth are laid precisely in the process of intellectual labor. Traditionally, intellectual education is correlated with the acquisition of new knowledge in the learning process, the development of appropriate skills. However, only $47.2 \%$ of the surveyed schoolchildren attend educational institutions that study the need for various educational services, $52.8 \%$ of children - the need for additional education, $62.9 \%$ - the need for specialized training. That is why only $58.4 \%$ of respondents are concerned about their academic performance in subjects which reflects the fact that modern schoolchildren do not realize the full value of education.

The development of the child's thinking process, as well as intellectual and mental mobility, the ability to independently conduct research work play an important role in the development of the child's personality. Therefore, we were wondering if the school has all the conditions for children to participate in project and research activities. Only $37.6 \%$ of schoolchildren answered this question in the affirmative. These indicators show that almost half of the surveyed schoolchildren are unable to realize their professional potential.

And are there any conditions in these educational institutions for the realization of the schoolchildren's creative potential? Only $40.4 \%$ of children surveyed indicated that educational institutions reveal their desires in organizing leisure activities. But at the same time only $31.5 \%$ of respondents answered in the affirmative to the question "Can schoolchildren find a club, section, study group suitable for themselves, participate in holding celebrations, competitions in your educational institution?". Consequently, the percentage of children who are satisfied with the organization of leisure and extracurricular activities was low and amounted to $37.6 \%$.

The arrangements for meals in general education institutions are of great importance for promoting a child's healthy lifestyle. However, in the question of food satisfaction, the indicators were low and amounted to only $25.7 \%$ of the total number of children surveyed.

Schoolchildren were asked to choose from the list of those personality traits that should be formed in students. 53.4-61.8\% of respondents included courage and selfconfidence, cultural behavior, broad outlook and omnifarious knowledge, honesty and decency, as well as self-esteem among the five most significant qualities of a modern 
personality. Patriotism, outer beauty, and attractiveness, affection for parents and family turned out to be less significant for the children. These data confirm the fact that there is no educational process at all levels of education. It is not surprising that only $27.5 \%$ of the surveyed children believe that their educational institution is the best among others. To an open question about what you understand by the quality of education, many schoolchildren marked "comfortable learning", some of the schoolchildren answered "clear teaching". "Are there conditions for the harmonious development of personality in your school?" The answer to this question makes us think because only $20.2 \%$ of schoolchildren answered in the affirmative, the answer of $41 \%$ was a definitive "no".

The full development of the child's personality should undoubtedly be harmonious, which means a comprehensive education based on the simultaneous and interrelated development of all aspects of the personality. If one of the sides is given insufficient attention, for example, physical or moral education, then this will negatively affect the formation of the personality as a whole.

\section{Conclusions}

The survey analysis revealed the lack of conditions for the harmonious development of the personality of those schoolchildren who participated in the survey. We should bear in mind that the harmonious development of the individual is determined by a significant part of the synergistic effect of the cumulative impact of education, cultural environment, health status on the child's personality. Mental education, physical education, moral education, aesthetic education are the main components of the comprehensive harmonious development of the child's personality. They should be combined with the development of the child's creative potential and abilities and the involvement of children in a feasible work process. This means that the question of creating conditions for the comprehensive development of the modern personality in Khabarovsk remains open.

\section{References}

1. I. V. Kostakova, L. I. Yafyasova, Vector of Science TSU. Series: Pedagogy, psychology, 3(34), 78 (2018)

2. S. A. Isaeva, Education of a harmoniously developed and socially responsible person within the framework of the Target model for the development of the regional system of additional education for children, 78

3. I. A. Cherkashin, Successes of modern natural science, 1, 86 (2004)

4. Ya. A. Amvrosyev, Pedagogical support of harmonious development of schoolchildren-athletes, 156 (2003)

5. L. S. Vygotsky, Imagination and creativity in childhood, 96 (1997)

6. N. N. Lyubimova, O. F. Neskryabina, Modern problems of science and education, 6 (2013)

7. M. A. Uaykhanova, Science for Education Today, 9(2), 200 (2019)

8. K. S. Gruzdova, Collection of materials of the All-Russian scientific-practical conference of teachers, undergraduates, and students "Days of Science - 2018" Novgorod branch of RANEPA, 136 (2018) 